OPEN ACCESS

Edited by: Marta Poblet,

RMIT University, Australia

Reviewed by:

Vanessa Teague,

Australian National University,

Australia

Jake Goldenfein,

The University of Melbourne, Australia

*Correspondence:

Miranda Imperial

mci30@cam.ac.uk;

miranda.imperia/@gmail.com

Specialty section:

This article was submitted to

Blockchain for Good,

a section of the journal

Frontiers in Blockchain

Received: 24 July 2020

Accepted: 19 March 2021

Published: 09 April 2021

Citation:

Imperial M (2021) The Democracy

to Come? An Enquiry Into the Vision

of Blockchain-Powered E-Voting

Start-Ups.

Front. Blockchain 4:587148. doi: 10.3389/fbloc.2021.587148

\section{The Democracy to Come? An Enquiry Into the Vision of Blockchain-Powered E-Voting Start-Ups}

\author{
Miranda Imperial* \\ Department of Sociology, University of Cambridge, Cambridge, United Kingdom
}

This research sets out to analyze the message promoted by start-up enterprises that apply blockchain technologies for the purpose of e-voting [blockchain-powered e-voting (BPE)], and their perceived effects of this technological solution on democratic outcomes. Employing Norman Fairclough's critical discourse analysis (CDA), I examined the written output of seven BPE start-ups (Agora, DemocracyEarth, Follow My Vote, Polys, Voatz, Votem, and VoteWatcher), as displayed in their websites. The close attention of CDA to power relations brought out relevant topics of discussion for analysis. Notably, these included: voting as an expression of democracy; technological determinism; individual versus communitarian understandings of democracy; the prominence of neoliberalism and the economic sphere; and technological literacy. Findings from the literature suggest that the assumptions of BPE start-ups about a blockchain-powered democracy diverge from widely accepted understandings of democracy. BPE start-ups envision a democracy determined by positions and institutions of power, by the technologically able, and by economic interests. This research argues that this conception of democracy disempowers voters from any form of decision-making regarding how democracy is run beyond their expression in the form of a vote decided by these established powers. The widespread addresses to existing elites to enable BPE, as well as what is left unsaid about community, collective rights and the not so technologically literate population, imply that BPE developers display concern for one particular expression among the many diverse and heterogeneous understandings of democracy, while disregarding outstanding privacy, security and accountability concerns associated to implementations of the technology for BPE. This work is a contribution to much needed research on technology and democracy's deepening intersections, at a time of rapid technological innovation and turbulent democratic scepticism.

Keywords: blockchain, critical discourse analysis, democracy, e-voting, start-up, technological determinism, technological literacy 


\section{INTRODUCTION}

The possibilities of use of blockchain technologies in the public sector have been thoroughly reviewed recently (Berryhill et al., 2018; Thomason et al., 2019). Besides any possible incorporation to the public sector of financial applications of blockchains, a field that is spearheading blockchain adoption in the private sector (Arslanian and Fischer, 2019), governments appear to be aware of the "transformative and potentially disruptive nature of this emerging technology" (Berryhill et al., 2018, p. 20), and several hundred initiatives are underway (Berryhill et al., 2018, pp. 20-22), many of them taking advantage of publicprivate partnerships as a means to jumpstart access to the technology (Berryhill et al., 2018, pp. 22-23). According to the American Council for Technology-Industry Advisory Council (American Council for Technology Industry Advisory Council (ACT-IAC), 2017) most areas of the public sector could benefit from the use of blockchains (Berryhill et al., 2018; Thomason et al., 2019). But it is perhaps the application of blockchains for voting that has become the most advocated (Allen et al., 2019), although outstanding security risks remain (National Academies of Sciences, Engineering, and Medicine, 2018; Park et al., 2020) that could hinder its widespread application and that have resulted in early failures (Juels et al., 2018; Goodman and Halderman, 2020).

Many abstract controversies regarding blockchain-powered e-voting (BPE) systems are likely to be tempered in the landscape emerging in the aftermath of the current COVID-19 pandemic, where "new normal" (Beck, 1992, p. 79) regulations are likely to make current methods of synchronous, in-person voting exceedingly cumbersome or unadvisable (Blessing et al., 2020). On the other hand, the need for alternatives to in-person voting is likely to intensify the scrutiny over privacy and security issues with those systems (National Academies of Sciences, Engineering, and Medicine, 2018; Park et al., 2020), as the recent November 2020 United States presidential election, with its widespread-although not necessarily well-founded-allegations of voting irregularities starkly highlighted.

Beyond technological, privacy and security aspects, there is a paucity of reports on the relationship between BPE intended applications and current understandings of social relations, as it can be expected from a relatively new technology that is beginning to enter a widespread adoption phase. This is particularly true regarding the implications that adopting this new technology may have for power relations. In this work, I center on the study of the power relations covert in communication between technology developers and users by analyzing how BPE start-ups communicate the means and ends of their products, their views on how their technology can impact democracy, and how they are shaped by the power relations implicit to the development of BPE. To that end, I will first review the relevant sociological literature on: (i) the impact of new technologies on society, particularly those related to technological determinism and its criticism; and (ii) current understandings of democracy and how they are impacted by alternative modes of voting, as these will become relevant in the subsequent empirical analysis of the messages BPE start-ups are advancing to promote their products and technology.

\section{LITERATURE REVIEW}

\section{Technological Determinism}

Scholarly attempts to discern the relationship between new technologies and society have tended to fall into the trap of technological determinism, that is, describing a purely causal relationship between technology and its-generally positiveimportant effects on society. There is a "strong tendency, especially when technologies are new, to view them as causal agents, entering societies as active forces of change that humans have little power to resist," communication around them becoming "deterministic" (Baym, 2015, p. 26). Examples abound in the literature (McLuhan, 1964; Fischer, 1992). Technological determinism is an "optimistic theory" that either fails to recognize the misgivings of technology, or believes negative outcomes stemming from technology can be eliminated by new innovation (Markus, 1994).

An informed discussion of technological determinism is crucial to a discourse analysis of communication of BPE, since descriptions of the technology are determinant in promoting its adoption. It is important to analyze the messaging around it, its developers' intentions and assumptions, conveyed in messaging: whether they conceive of BPE as an innovation to induce radical, positive change unto the world, and whether they adhere to logics similar to those of technological determinism. Such technologically "utopian" ideas (in Nye, 1997) tend to see technologies as "natural societal developments", as "improvements to daily life," and as "forces that will transform reality for the better" (Baym, 2015, p. 28). The yardstick of democratic ideals that most Western liberal societies adhere toand that the world now adheres to through the West's colonialist imposition of its aspirations-is something which BPE addresses, albeit covertly, in their messaging.

Technological deterministic narratives have been associated to the promotion of democratic ideals in the literature before. Some academics have deemed the creation of the Internet a "renaissance of democracy" (Agre, 1994, cited in Curran. 2016), and a "revitalized democracy characterized by a more active informed citizenry" (Corrado, 1996, in Levin. 2002, p. 81). Similarly, Castells has stated that "dictatorships could be overthrown with the bare hands of the people" thanks to the power of a technology: the Internet $(2012$, p. 1). This is not a new thought, as much has been written about social media's promotion of platforms and media where "participatory" agency is created (Fuchs, 2013, p. 26). Others, like Jenkins (2008, p. 137) and Shirky (2009, p. 107) have further remarked how the Internet goes beyond economic facilitation and empowers "consumer participation" (Jenkins, 2008, p. 137) and "participatory engagement" (Deuze, 2007, p. 95), enabling conversation and action.

I draw on this theory because the conveyance of blockchain's new and improved privacy, anonymity and efficiency capabilities might well fall into technologically deterministic writing, or at 
least, follow a trend in theories linking emerging technology and the current transformation of democracy. Directly relevant to voting, the emergence of Internet-mediated platforms showed, for many, that "the public would gain unprecedented access to information, and be better able to control government" (Toffler and Toffler, 1995, in Curran, 2016), and "empower [.] previously excluded groups" (Poster, 2001, p. 175) via more horizontal avenues of communication. Ideas about the Information Society's "democratic and decentralizing" power (Garnham, 1994, p. 43) are widespread. Some have even called the Internet a "liberation technology" (Diamond, 2010, p. 71).

Regarding e-voting, academics have discussed it as a potential end of Internet-mediated democracy. It has been linked to direct democracy (Grossman, 1996, p. 250) as, through it "voters will have a voice that reaches directly to the highest levels of both parties and the government" and it will "bring accountability directly to bear on elected officials" (Rash, 1997, in Levin, 2002, p. 82). It remains to be seen whether communication around blockchain's adoption for e-voting purposes will fall into these technologically utopian commentaries or whether it will bring about different implications for the democratic aims to be sought after in modern societies.

\section{Criticism of Technological Determinism}

Critics of this kind of optimism over the web 2.0 regard it as spreading an ideology serving corporate interests (Van Dijck and Nieborg, 2009; Fuchs, 2011). This line of criticism of academics overly relying on technological innovation for its explanation of societal trends, have also developed different ideas on the side, beyond circular narratives of "technology shap(ing) technology" and society (Ellul, 1964, pp. 85-94; Winner, 1977, pp. 57-73, in MacKenzie and Wajcman, 1989). Many of these social theories are important for this research, as they, unlike technologically deterministic accounts, do not fail to explore power relations emerging from the creation and adoption of new technologies.

For some social scientists, the consequences of technology are not just innovation in hardware and software or economic benefits, rather "they apply to all areas of social life" (Schroeder, 2007 , p. 9). Social construction of technology approaches developed by Wiebe Bijker and Trevor Pinch (Bijker et al., 1987; Bijker, 1995), to the contrary from technological determinism, see "technology and society as continually influencing one another" (Baym, 2015, p. 26). Placing agency in people's hands as creators of technology (Nye, 1997, p. 151), these theories are more fitted to observing decisions taken by technology developers, as they are "seen as dependent on their social contexts which are, in turn, shaped [...] by communication" (Baym, 2015, p. 44). This is why this approach is particularly relevant to an analysis of BPE. There has further been much written about the "prosumer," with the "blurring of the line that separates producer from consumer" (Toffler, 1980, p. 267), showing how individuals, even beyond the creators themselves, can shape technology in their everyday life usage. However, the fact that BPE is not a platform for conversation might make these theories less relevant to this particular avenue of research. I adopt Winner's thesis that "technologies [.] can be inherently political" (Winner, 1989, p. 33), since they "can be designed, consciously or unconsciously, to open certain social options and close others" (MacKenzie and Wajcman, 1989, p. 4; see Winner, 1989, p. 32). This is an important idea that will emerge as pertinent to an analysis of BPE. Ultimately, Mackenzie and Wacjman's thesis, that “it is mistaken to think of technology and society as separate spheres influencing each other: technology and society are mutually constitutive" (MacKenzie and Wajcman, 1989, p. 23) will inform the analysis of my research.

\section{Blockchain-Powered E-Voting and Democracy}

I decided to explore democracy as an analytical benchmark since blockchain applications for e-voting deal with voting as a concept, and voting is crucial to democratic aims, values and ends, albeit not the one key defining feature of democracy, as we will see below.

The relationship between voting and democracy is delimited by the concept and fundamentals of democracy. Different definitions of democracy exist, with some recent understandings of the term taking into consideration data and algorithms ("linked democracy," Poblet et al., 2019) or blockchain technologies ("cryptodemocracy," Allen et al., 2019). Within the context of this research, Bernard Crick's remarks seem appropriate:

[A]ll can participate if they care (and care they should), but they must then mutually respect the equal rights of fellow citizens within a regulatory legal order that defines, protects, and limits those rights. This is what most people today [...]. ordinarily mean by democracy-let us call it "modern democracy," ideally a fusion [...] of the idea of power of the people and the idea of legally guaranteed individual rights. The two should, indeed, be combined, but they are distinct ideas, and can prove mutually contradictory in practice (Crick, 2002, p. 13).

At the root of common conceptions of democracy, citizens can freely exercise their opinions on how to be governed via vote, either to choose representatives or to give their opinion on an issue, and they will abide by the decision of the majority. However, individual voters can have very little influence on the outcome of an election, and this can discourage them from voting. As early noted by Condorcet (McLean and Hewitt, 1994, pp. 245-246), or Hegel (1991), this can discourage voting and pose hindrances to participation and commitment to democratic ideals. Notably, I observe an underlying tension in defining democracy that Crick has masterfully outlined: that between the participatory, communal and emotional "power of the people," versus "individual rights." Both of these are needed for a functioning and normatively "good" democracy according to Crick's widely accepted definition. Therefore, I will take this definition and these two elements as the benchmark against which BPE start-ups' assumptions about democracy will be judged.

In his 1957 attempt at modeling political decision-making in democracies, Anthony Downs highlighted the high opportunity cost of voting, which thereby led to a paradox: by voting, rational citizens do not maximize the expected utility. Therefore, why do they vote? (1957, pp. 244-246). Followers of Downs have 
supported instrumental theories of the rationality of voting (Grossback et al., 2007; Noel, 2010).

Critics of this rational choice framework hold that voters wish to voice their opinions and their ideas through their voting. This is at the root of the expressive theory of voting, advanced by Brennan and Buchanan (1984); Brennan and Lomasky (1993), and Hillman (2010), that "sees the vote as expressing support for one or other electoral options, rather like cheering at a football match" (Brennan and Hamlin, 1998, p. 149). Despite all of the above, most people believe they have a moral obligation to vote (Mackie, 2015), although the exact reasons why this belief arises are controversial (Brennan, 2016). In fact, expressivist theorists believe there is no duty to vote (Brennan and Lomasky, 1993) in countries where voting is a right rather than a duty. Besides the above, is there a moral obligation regarding how citizens vote? Influential theorists in the history of democracy, such as Mill and Rousseau have argued that voters should cast their vote for the common good, beyond self-interest (Mansbridge, 1990). Along similar lines, expressivist theorists claim that voters become attached, in a morally significant way, to the ideas defended-and implemented in case of victoryby their candidate (Brennan and Lomasky, 1993, p. 186). If the conclusion is that voting is morally important, these views would vary greatly from Downs' rationalist approach. Further, by virtue of ascribing a need and a morality to voting, voting becomes, by necessity, something crucial for a community, as its importance is greater than that of one choice in many in an individual's day. These considerations are fundamental for this research, as I will be analyzing with which connotations blockchain e-voting producers speak about and approach voting. Whether voting is considered an individual or a collective action, and its importance, will be essential in relation to the democratic outcomes these technology developers wish for.

Within voting, we must look at e-voting more concretely, as this is the technological innovation that BPE is advancing. There is a large body of work regarding voting methods. Current research suggests that no voting method outperforms the rest in all situations (reviewed by List, 2013).

E-voting is just the last of a series of "convenience voting" solutions implemented over time (Gronke et al., 2008). In e-voting, "voters are provided a method of signing into a secure website [...] and cast their votes using a web browser" (Gronke et al., 2008, p. 441), although a more comprehensive definition should reflect that, in e-voting, the voter's intention is recorded electronically rather than on paper. Gibson et al. (2016) have recently highlighted the many challenges of e-voting, more demanding than those of, for example, e-banking: (a) authentication, (b) anonymity/privacy; (c) verifiability/auditability. Most importantly, voter coercion can be an issue in remote e-voting.

Proponents of e-voting and advancements in voting technologies, like Krimmer (2012), believe that ICT radically changes the framework of representation, as it allows new and more direct interaction with representatives. It also provides solutions to old problems (like voting from far away or remote places). Finally, it offers the promise of increasing turnout both through its facilitation of the voting process (Krimmer, 2012) and by increasing participation of the youth in the political process (McAllister, 2016), an effect that is not observed with late adopters (Richey and Zhu, 2015). A recent example of these benefits can be found in Indonesia, with the world's fourth largest population (close to 300 million) spread over 17,000 islands, and where democratic voting processes are severely hampered by weak and insufficient electoral infrastructures. The application of a BPE technology has shown much promise of improvement over traditional voting systems (Van Niekerk, 2019). Many of these potential advantages are presently offset by outstanding limitations of current technologies centering on security-vote preservation and certification-and privacy-authentication and anonymity-issues (Gibson et al., 2016; National Academies of Sciences, Engineering, and Medicine, 2018; Park et al., 2020). Owing to these, some electoral systems-such as Switzerland (Kuenzi, 2019)-have halted any further development of BPE systems, whereas others, such as Russia, appear to keep on pushing for BPE, despite initial, security-related setbacks (Kapilkov, 2020).

In this work, I argue that a vision of technology and democracy through power relations is crucial to uncover what might be hidden behind assumptions made by the communication of innovation. I show that BPE start-ups, rather than focusing on procedural matters, such as appealing to the efficiency and ease of their offered BPE product, choose to focus on the democratic achievements of their technology, and on its creation for the betterment of democracy.

Through critical discourse analysis (CDA), I investigated the perceptions of BPE start-ups on technological determinism vis-à-vis democratic ends and outcomes, relating back to understandings of power relations and to democracy, an elusive, heterogeneous concept where tensions between communal participative, bottom-down perspectives coexist with institutionalized practices granting an individualized set of rights. All of this will help us address how new technology for democracy (in the form of BPE) confronts this intersection.

This research centers on the application of blockchains to e-voting, a form of voting online mediated by the blockchain. Voting is intrinsically related to democracy, and thus, to citizen participation and representation in government. Representation is all important in democracy, but it is biased by inequality. In fact, rampant inequality is at the basis of the ills of present democratic systems (Fitzi et al., 2018; International IDEA, 2019). Power relations here are crucial, and must be explored when dealing with the emergence of a new technology (intrinsically linked with economic rationale, profit accumulation, ...) and its relationship to democracy. As summarized above, there is a dearth of theoretical studies linking BPE and democracy, however, such a paucity can be in itself a consideration for "power relations" (Robins and Webster, 1988, p. 52). Through a CDA of how developers of this new technology market and communicate their products I aim at uncovering assumed power relations (who this technology is directed to, who has the right to use it, ....). I also aim at contributing to the academic literature linking BPE technologies and democracy by analyzing how BPE developers view the state of democratic values today and where democracy is headed. 


\section{MATERIALS AND METHODS}

\section{Conceptual Framework}

The fact that BPE is a technology in a stage of recent development and being newly adopted by consumers means that there is little content addressing and describing it besides that crafted by its creators. Therefore, I embarked on examining textual content produced by BPE start-ups, describing their products and the reasons for using them. I believed the assumptions comprehended in what is written (and what is not), in tone, directed audience and structure, would be indicative of the thoughts and stance of the developers of this technology, that so directly seeks to impact democratic outcomes. A preliminary examination of these materials made it clear that texts provided by BPE start-ups focused on democracy itself, the technology's ultimate achievements, rather than on implementation, deployment logistics or technological functionality. Surprisingly, little attention appeared to be paid to technology adoption by final users, the voters, suggesting an underlying assumption that "code is law" (Lessig, 2006; De Filippi and Hassan, 2016), that people can use the technology. This involved a complexity in the textual analysis that would be best approached through the use of CDA as the methodology of analysis because it includes rich, detailed, in-depth textual analysis of a carefully selected number of sources (Fairclough, 1995; Wodak and Meyer, 2009).

The intrinsic interest of this research approach was compounded by the fact that there is a significant gap in CDA approximations to blockchain applications for any industry. I anticipated the assumptions around power relations made within texts marketing these technologies to be especially covert by the use of technical jargon in the form of complex technological lexis. All these reasons set the scope of my research around the analysis of final, published texts of BPE for textual, discursive and societal features (Fairclough, 1995).

Critical discourse analysis as an analytical method relies on broader academic theory surrounding discourse analysis and its identification of the embodiment of power relations in language (Fairclough, 1989, 1992). Past research around discourse analysis has put forward the idea that "our use of language in particular (is) bound up with causes and effects which we may not be aware of under normal conditions" (Fairclough, 1995, p. 54). Language is perceived to be more than just an innate and natural function enabling communication. Proponents of discourse analysis have theorized that language conveys a set of assumptions and understandings about the world that are "historically and culturally specific and relative" (Gill, 2000, p. 173). Because of this importance of contextual factors, the discursive "is a space for dispersion, it is an open field of relationships" (Foucault, 1968, p. 10). Discourse analysis further brings about a clearer understanding of "assumptions" (Altheide and Schneider, 2013, p. 2) that might appear within the construction of concepts (Gill, 1996, p. 144) in the language employed. This study of assumptions presents itself as essential to perceive factors such as the "limits and the forms of expressibility" as well as of "conservation: [...] those which are repressed and censured"
(Foucault, 1968, p. 14). The study of what is not said in a text, as well as the apparent purpose of the content and the people it is addressed to, distinguish discursive forms of textual analysis from other methods. This is the main reason why CDA was chosen to conduct detailed, in-depth research of assumptions in the texts advanced by BPE start-ups. The small number (seven) of search-engine discoverable start-ups for BPE existing in the market suggested that an in-depth critical appraisal of their online materials according to discourse analysis was feasible and should be done.

\section{Research Design}

Within available practices of discourse analysis, CDA as theorized by Fairclough (1995), appeared to be particularly fit to analyze the power relations established between the views of technological developers as reflected in text form, and democratic goals and values. CDA goes further than observing the "content, organization and functions of texts" (Gill, 2000, p. 187) and interprets that all social interactions are mediated through language (Fairclough, 1995). Its capacity for "relationality" (Fairclough, 1989, p. 3) and "transdisciplin(arity)" (Fairclough, 1989 , p. 3), make it well suited to find implicit connections between expressions as diverse thematically as those concerning technological innovation and democracy. Furthermore, CDA goes beyond other discourse analysis genres (such as narrative analysis) in being particularly "sensitive to power relations" (Fairclough, 1992). Unlike other discourse analysis frameworks, it picks up "power, ideology and inequality issues" (Blommaert and Bulcaen, 2000, p. 447) in a close reading of texts. Fairclough's CDA $(1992 ; 1995)$ revolves around three areas of analysis: the Textual (consisting of discourse-as-text and micro language choices), the Discursive (looking at contextual, speech acts and intertextuality) and the Societal (viewing discourse-as-socialpractice, within ideological and hegemonic processes). Altogether these are particularly perceptive of power relations implied within the forms of communication of texts. Academic research exploring technology and democracy that has foregone power relations in the past has been criticized for this omission, as I have observed above. The research fields of technology and democracy and their interaction, having much to do with representation of voices, which voices matter most and who has the power to design creative technological outcomes that end up "mattering," show that a method, such as CDA, that prioritizes power relations is needed for this research.

Critical discourse analysis has intrinsic limitations due to the influence of context and researcher bias. Many of these have been highlighted in the literature (Wodak and Meyer, 2009; Wodak, 2014, p. 311). Despite these limitations, CDA is still the only method providing the necessary amount of detail and "self-reflection" to an emergent topic that deeply requires "new responses and new thoughts" (Wodak and Meyer, 2009, p. 32), such as BPE. In this instance, CDA can help uncover associations between topics according to context. It also shows that "there is no neat separation between the meanings in language and in the social world" (Taylor, 2013, p. 78). This is important to the nature of this research: rather than valuing the benefits or shortcomings of BPE in itself, it is what BPE technology 
developers express about BPE that will be analyzed. Thus, it is only through CDA that such an acute drawing out of social relations as is needed can be undertaken. Along these lines, criticisms of CDA as producing interpretation rather than fact feed into a "notion of truth" (Taylor, 2013, p. 82), dichotomizing facts and interpretation into binary opposites. This criticism hardly applies here, given that, as mentioned above, I will be focusing on production and construction of meaning far beyond the mere reporting of facts, and exploring how technological innovators describe their products.

To use CDA empirically, I adopted Gill's (2000, pp. 188189) systematization of the steps to follow in order to undertake discourse analysis, as she provides a good foundation on how to approach a broad research question. This was useful in countering the aforementioned lack of order or clarity in process in conducting CDA with texts.

\section{Sample Selection}

A Google web search engine exploration for BPE start-ups was carried out during the month of April 2019. After a thorough search for the most prominent start-ups, and scouring through some online media articles talking about different BPE emerging start-ups, seven start-ups with Internet presence that used the Web to communicate about their BPE products in English were chosen. This small number of start-ups was well-suited for CDA and ensured the possibility to fully examine all of the content in their websites, including attached pdfs, white papers and blog posts concerning their products. The chosen start-ups were Agora, Democracy Earth, Follow My Vote, Polys, Voatz, Votem, and VoteWatcher (Table 1), and all the materials from the web pages that were the subject of my analysis were collected during the months of April and May, 2019. As of May 1st, 2020, the relevant contents had not been changed.

\section{Analytical Procedures}

Since web materials did not require transcription, I moved on to "skeptically read and interrogate the text" (Gill, 2000, p. 189), familiarizing myself with the content and keeping the research objectives in mind. Following Fairclough, language was appraised as Textual, Discursive or Social. According to these categories, texts were analyzed and annotated for implicit and explicit references having to do with technology's role in the government of society and in democratic values, and technology and power/agency. This involved comparing variability in data (frequency and presence of different elements, placement on the web, visibility, rhetorical force, ...) as well as forming hypotheses about what I uncovered.

\section{RESULTS AND DISCUSSION}

The CDA conducted covers the bulk of the publicly available information offered in their web pages by seven BPE startups: Agora; Democracy Earth; Follow My Vote; Polys; Votem; Voatz; and VoteWatcher (Table 1), following Fairclough's threedimensional canonical model: textual, discursive, and societal (Fairclough, 1995). Due to spatial constraints and to the copious amount of suitable materials, mainly themes of interest that recur throughout the seven start-ups will be highlighted. However, some points of nuance and division among these that contribute toward general conclusions will be included.

Some challenges to the CDA are worthy of mention, notably, the abundance of data in the seven websites, as well as the general lack of discursive data due to the "newness" of blockchain for e-voting. Despite these limitations, analysis of BPE start-ups' content allowed me to scrutinize the vision that technology entrepreneurs have for the future with relation to existing power relations. The content of the analysis largely focused on discourses of change, governance, technological ability and links between democracy and productivity, and between democracy and capitalism.

\section{Failing Methods, Technological Solutions: Democracy Reduced to Voting}

On the whole, the seven start-ups studied introduced widespread claims of problems that plague current democratic organizations. Most of them highlighted flaws in current voting systems and their subsequent hinderance to democracy. Agora, Vote Watcher and Follow My Vote, especially, outlined the problems existing with current voting technologies. Paper ballots and Electronic Voting Machines were denounced as being "slow, costly and exposed to many vulnerabilities that can inhibit free and fair elections" (Agora, 2019b, p. 4). Textual analysis here identified the use of a highly descriptive lexis, including adjectives or descriptive phrases loaded with negative connotations referring to existing voting technologies. Similarly, vocabulary such as "voting machines used in the 2012 election were over a decade old, running outdated software that took only $15 \mathrm{~min}$ to hack into?" (VoteWatcher, 2019) was directly followed by "We are using the latest operating system with the most up to date software" (VoteWatcher, 2019) as an effective juxtaposition. Like Agora, Vote Watcher displayed the new technology as necessary: the flaws of the past technological advancements in voting prescribe the need for a new technology that solves all of these issues. Follow My Vote went as far as giving a granular, page-long analysis of different voting machines' use cases (Follow My Vote, 2019c), from which the following takeaway was drawn:

Several things can be learned from these system failures. First, the machines must be physically sound. Second, the programming must not have holes that can be exploited. Third, it's not best practice to have extremely simple and guessable passwords hardwired into a voting machine.

This statement presents data in a simplified, matter-of-fact manner. The repeated use of modal verb "must," as well as the simple and very direct wording of the list (with very factual adverbs like "First. .." "Second" and "Third" introducing the "things (that) can be learned from these system failures") are important to carry meaning forward. This enumeration prescribed what a voting technological ideal was for Follow My Vote. Through dichotomy and drawing out particular existing issues in voting technologies, start-ups were more effective at pushing the importance of their technology onto readers' perceptions, while purposefully ignoring unresolved 
TABLE 1 | Blockchain-powered e-voting startups chosen for study.

\begin{tabular}{|c|c|c|}
\hline Startup & Country & Description \\
\hline $\begin{array}{l}\text { Agora } \\
\text { (https://www.agora.vote) }\end{array}$ & Switzerland & $\begin{array}{l}\text { Initiated in } 2017 \text { (Swiss Lab \& Foundation for Digital Democracy, Leonardo Grammar). } \\
\text { Wide media exposure after their technology was used in a recent general election in } \\
\text { Sierra Leone }\end{array}$ \\
\hline $\begin{array}{l}\text { Democracy Earth } \\
\text { (https://democracy.earth) }\end{array}$ & International & $\begin{array}{l}\text { Open-source, collaborative enterprise, started in Argentina by Santiago Siri and Pia } \\
\text { Mancini (NET liquid democracy political party). In } 2015 \text { they joined other developers } \\
\text { and hacktivists to start the Democracy Earth Foundation, an international collective } \\
\text { united by the vision that distributed ledger technologies can reverse some of the ills of } \\
\text { democracy today: "low participation, polarized endogamy and eroded trust in } \\
\text { governing institutions" (https://words.democracy.earth/about). }\end{array}$ \\
\hline $\begin{array}{l}\text { Follow My Vote (https: } \\
\text { //followmyvote.com) }\end{array}$ & United States & $\begin{array}{l}\text { A "non-partisan public benefit corporation [...], founded on the principles of freedom, } \\
\text { as a tribute to the Founding Fathers of the United States [... . to promote truth and } \\
\text { freedom by empowering individuals to communicate effectively and implement } \\
\text { non-coercive solutions to societal problems." It aims at "improving the integrity } \\
\text { standards of voting systems used in elections worldwide" through the use of } \\
\text { blockchain technology (https://followmyvote.com/about-us/). The brainchild of Adam } \\
\text { Ernest, Nathan Hourt and Will Long, it is based in Longmont, CO, United States }\end{array}$ \\
\hline Polys (https://polys.me) & Russia & $\begin{array}{l}\text { An "online voting platform based on blockchain technology and backed with } \\
\text { transparent crypto algorithms." Promoted by the Kaspersky Software Lab (Moscow). }\end{array}$ \\
\hline Voatz (https://voatz.com) & United States & $\begin{array}{l}\text { Founded in } 2015 \text { and devoted to the development of blockchain-powered mobile } \\
\text { voting systems that allow voters to cast their e-vote from their mobile phones. Based } \\
\text { in Boston, MA, United States }\end{array}$ \\
\hline $\begin{array}{l}\text { Votem } \\
\text { (https://votem.com) }\end{array}$ & United States & $\begin{array}{l}\text { Offering a "revolutionary mobile voting platform designed to securely cast votes in } \\
\text { elections across the globe." It was started in } 2014 \text { by Pete Martin and it is based in } \\
\text { Cleveland, } \mathrm{OH} \text {, United States. }\end{array}$ \\
\hline $\begin{array}{l}\text { VoteWatcher } \\
\text { (http://votewatcher.com) }\end{array}$ & United States & $\begin{array}{l}\text { A voting platform launched by Blockchain Technologies (MA, United States), "a voting } \\
\text { system for the } 21 \text { st century [...] focused on transparency and efficiency and all of the } \\
\text { code is open source or available for inspection. It runs on off-the-shelf hardware. } \\
\text { Simple paper ballots make it easy for the voter. Detailed election records are posted } \\
\text { online and on the blockchain. Every step in the process is highly auditable." }\end{array}$ \\
\hline
\end{tabular}

privacy, security and overall accountability issues that have been repeatedly associated to these technologies and recently summarized by Park et al. (2020). Also significant to broader research is, perhaps, a societal analysis of what remained unsaid in BPE start-ups' content dealing with the flaws of modern voting. Causal links drawn between the failures of democracy and the necessary solutions that BPE offered imply that: (a) how voting is currently conducted is the main problem existing for democracy, and (b) a reform to how voting is done will be the answer. This line of argument thus ignored other pressing issues outside of the boundaries of voting, such as the irruption of populism, the rise of democratic discontent, or corruption by elected representatives. Importantly in my CDA, I observed that many of the existing power relations in society were ignored by the seven start-ups scrutinized. Imbalances of power such as the aforementioned were disregarded by a reductionist line of argument that brings down democracy to one of its many expressions: voting. This subject, the conflation of democracy with voting, appeared recurrently throughout my analysis.

\section{Efficiency, Capitalism-Monetary Concerns? Beyond the Democratic?}

As aforementioned, existing problems in technologically aided voting were a focal point of most of the analyzed websites. BPE start-ups presented these chaotic methods against the orderly, scientific promise of the blockchain. Such expressions could be found within the start-ups' mission and vision sections of their websites. For Democracy Earth, this was "the need to make our shared home a place of peaceful coexistence" (Democracy Earth, 2019b, p. 2). For Follow My
Vote, it was "to promote truth and freedom by empowering individuals to communicate effectively and implement noncoercive solutions to societal problems" (Follow My Vote, 2019a). Polys wanted to "change the way people vote" (Polys, 2019 b, p. 2). However, despite stating these ideas, expressed by abstract nouns, an emphasis on changes to proceduralism over form and ideas was a common thread that could be observed across different start-ups' written expression. Within the textual dimension of CDA, I encountered many instances where the democratic process was referred to in a highly detached, scientific manner. The little concern for emotion and emotional language showed BPE start-ups' focus on productivity, efficiency and securitization of the means for democracy. But no reference to ideas of communitarianism, equality or justice conveyed in democratic thought (e.g., Rousseau) was made. This emphasis on such a means of democracy for success was repeated throughout the texts. Certain lexical choices employed throughout the corpus displayed this, e.g., "electoral procedure" (Agora, 2019b, p. 4). This noun, "procedure," conveys a potential for mechanical, technological operationalization, to enact more effective and productive action, in order to facilitate democratic outcomes.

It could be argued that a focus on operationalizing means and efficiency may be associated to scientific language because BPE start-ups were, at their core, proposing a technological product. However, the appearance of lexis like "incentivizes" (Democracy Earth, 2019a), "voting systems" (Democracy Earth, 2019b, p. 2), "Governance as a service" (Democracy Earth, 2019a), . . . indicates something different. The societal dimension of CDA links language signaling more efficient and cost-effective 
operations to capitalism and the economic sphere. What this indicates in relation to power relations is that BPE start-ups operate beyond ends purely focused on democratic outcomes, and hints at the economic forming a large part of how their ideal voting "procedures" are to be developed and deployed. The languages of technology and capitalism converged in this frame. Beyond occasional expressions of the more emotional values behind democratic theory: "While money is the language of self-interest, votes express the shared views of a community. Political currency is not strictly meant for trade but for social choice" (Democracy Earth, 2019b, p. 8), start-ups were primarily concerned with both democracy and the economic, as exemplified by the following Democracy Earth quotation:

\section{Although politics and economics are often perceived as different realms, history teaches that money means power and power means votes. In order to effectively promote democracy it is essential to address both (Democracy Earth, 2019b, p. 15).}

As I noted previously, this acute concern with the antidemocratic flaws of existing voting procedures, coupled with ideas of vote "incentivization" and efficiency, display a stark reality. The current state of the economy is a capitalist one, whereby start-ups present business models whose main purpose is to develop a profit-making mechanism for themselves and for their investors. Discursively, I found a similar trend: investors were a crucial warrant of accountability for the subjects of my analysis. Though most websites avoided referring to them, venture capital funds such as Fenbushi Capital (powering Agora) were mentioned.

Papacharissi (2014) identified the crucial role of affect and the emotional for democracy, especially in times of election and electoral campaigning. BPE start-ups, however, neglected this dimension and presented a radically opposite view: they considered the pure act of voting as the expression of democracy. By doing so, they proposed a mechanistic, operational ideal, and ultimately showed a highly polarized view within the political scenario.

The observed connection between the development of new technologies for democracy and economic motivations requires further exploration, and opens up grounds for research in future work.

\section{Who? Audiences and the Issue of Voice}

Discursively, CDA allows for a meticulous insight into the treatment of voice in BPE start-ups' literature. A common trend that I will outline here is that, interestingly, the perceived existing "flaws" of democracy singled out previously, tended to be framed in the texts from the lens of the individual subject. Quotations such as "Every eligible individual should be able to actively participate in democracy by easily and safely voting when, how, and where they want" (Votem, 2019b, p. 3) were dotted throughout the texts, thus centering the problem and potential solution around the rights of individual citizens. The promise behind BPE start-ups' services appeared as an improvement for the individual citizen within a democracy. Quotes such as the aforementioned, and similar ones, like "Follow My Vote's mission is to promote truth and freedom by empowering individuals to communicate effectively and implement non-coercive solutions to societal problems" (Follow My Vote, 2019a), focused on the individual as the main subject existing vis-à-vis democratic institutions and being addressed by the radical positive changes of the blockchain. This notion has important implications for power relations. BPE start-ups generally, and Votem and Follow My Vote more specifically, conveyed that they conceive of voting and democratic outcomes as, ultimately, an atomized, individual choice, echoing rational choice theory models such as that proposed by Downs (1957). The start-ups under scrutiny thus showed little interest in comprehending or adopting more communitarian understandings of democracy and participation. This point reiterates and aligns well with the previous finding of a lack of emotional and social participation in the ideal future of democracy that BPE start-ups foresaw. Rather, these startups sought to transform democratic practice for the better by guaranteeing the fulfillment of democratic ideals to individuals and individuals alone. This, again, represented a way of avoiding communitarian ideas of democracy. In doing so, BPE start-ups appeared to very much side with the current statu quo, a statu quo that is being questioned by citizens in the wake of the last global economic crisis (Ancelovici et al., 2016).

In addition, and very importantly for the discursive sphere of the CDA, is who (the Audience) these messages are subliminally designed to be read by. I explored who it is that the BPE startups were attempting to reach with their literature, who it was that would be interested enough to read and consider their output. In several instances, there was written content in their websites that was under lockdown for the general Internet public, and could not be accessed unless you were a client or in touch with the business (e.g., Voatz, with a mostly locked down page). Voatz openly marketed itself toward electoral administrators, with "Are you an election administrator interested in trying out Voatz at your next federal, state or local election? Contact Us" (Voatz, 2019) as the question introducing their contact form. This makes it clear that the expected audience of the product were people already involved in the implementation of democratic practices.

Other websites presented similar focal points. Agora "work(s) together with vote administrators and politically neutral thirdparty organizations to implement fair and trusted voting systems" (Agora, 2019a) and alluded to their authority as making their "consensus framework" run right, over choosing to assign this role to, say, impartial voters. Follow My Vote attempted to include voters in its rhetoric more than other more institutionally minded websites (perhaps due to the fact that its code is opensource). It did so with expressions such as:

\begin{abstract}
No one except for election officials really knows what happens to your vote once you cast it, so it's not surprising that more and more research is showing that citizens don't vote because they don't believe their votes count. Understandably, these frustrated voters are losing confidence in our democratic system (Follow My Vote, 2019a).
\end{abstract}

However, and despite this claim, there were areas of the website where authority and decision-making power were not as radically shared. Quotations such as "after all, in an election, it's not who votes that counts, it's who counts the votes!" 
(Follow My Vote, 2019a) emphasize this, as do web sections such as "Benefits for Candidates" and "Benefits for Registrars," only countered by a single "Benefits to Voters." Therefore, I argue that it is possible to trace a democratic asymmetry inherent in these start-ups' "democratic" ends. This analysis challenges the extent to which the products that BPE start-ups introduced are that ground-breaking, or even, "democratic," given that existing institutions continued to be thoroughly involved with guaranteeing the running of democratic outcomes, and average citizens continued to be excluded from decisions surrounding electoral processes. The Voatz website stated the product will benefit "overseas" and "military" voters who found it difficult to participate in elections before (Voatz, 2019), however, the discursive aspects of my analysis display that the text (the solution to their troubles) is clearly not including them as active participants in the creation of opportunity for their involvement. What this signals, accordingly, is an inherent power asymmetry in the way these start-ups address audiences. By restricting BPE implementation to existing institutions and not involving citizens in the process, the start-ups under scrutiny fell into representing a product that has not been democratically implemented and decided upon, but rather, one that would be imposed by existing institutions, the same existing institutions that are being attacked by present-day critics of the democratic status quo. Overall, the acute emphasis these start-ups placed on individualistic interpretations of democratic processes, together with their dialog with existing institutions and representatives in power, display a replication of present-day power relations. This questions to what extent BPE is a ground-breaking force with a great potential to democratize governance.

\section{Technological Determinism}

A common aspect in the message put forward by BPE startups is the emphasis on the positive overtones of the relationship between technology and normative goodness. An example is given in the following quote:

With internet growth reaching over 3 billion lives [...] there's no reason stopping mankind from building a borderless commons that can help shape the next evolutionary leap for democratic governance at any scale (Democracy Earth, 2019b , p. 3).

This fits into societal discursive analysis and displays a concern for the power relations embedded at the crux of technology and democracy. Democracy Earth also stated that "The next Silicon Valley is not in a faraway land or on any land at all, but a new frontier of the internet itself rising as the one true open, free and sovereign network of peers" (Democracy Earth, 2019b, p. 24). Both the direct causal link between "internet growth" and "shap(ing) the next evolutionary leap for democratic governance" shown in the first quote, and the hyperbolic language: "the one true open, free and sovereign network of peers," employed in the second, act similarly. These passages depict a causal relationship between technology and democracy, with technology being expressed as the solution to democratization and giving voice to a population.

The intrinsic relationship established between e-voting startups and technology and its widespread benefits reminisce of the technologically deterministic discourses of technological hype and utopia surrounding the origin of the web and the web 2.0, stemming from Silicon Valley (Castells, 1998, 2012). Therefore, whilst it is in the start-ups' interest to put forward a claim where their technological innovation is seen as indispensable for the future of our democratic values ("it is impossible to envision the future of democracy where digital elections are not the global standard" Votem, 2019b, p. 3), there are overarching discourses identifying broader ideas about the world at play. One such allusion was displayed in the following example: "the mere existence of risk should not preclude technological progress" (Votem, 2019b, p. 3). The intrinsic relationship between technological innovation and capitalism was alluded to through connotation, through words evoking investment, such as "risk." This is representative of the power embedded in the funding and expertise required to develop these technologies. This, and its relationship with a better future says a lot about who they envision as bringers of a promising future and what kind of skills and resources are needed for this.

Much of my discussion around technology in the textual dimension of CDA follows this societal enduring discourse too. My analysis highlights that start-ups believed in "empowering" voters through their technology:

We are tapping on delivering a human right that can effectively empower individuals that will have to face the coming challenges of automation (Democracy Earth, 2019b, p. 20).

Follow My Vote's mission is to promote truth and freedom by empowering individuals to communicate effectively and implement non-coercive solutions to societal problems (Follow My Vote, 2019b,c, p. 2).

This indicates that BPE platforms view voters as a largely disempowered commons that can achieve the empowering that democracy should bring about through technological innovation (as argued above) powered by capitalism and Venture Capital.

\section{Technological Literacy}

Finally, voice and technology meet around the issue of technological literacy. There was a multiplicity of statements that indicate the existence of complex power relations between technological innovation and the promise of democratic, fair and equal political futures. Several pressing problems were singled out in these start-ups' literature, problems that must be solved to uphold the feasibility and realization of democratic government. One of these is participation. Sentences like:

Democracy can't function if almost half of citizens aren't voting; and in this regard Follow My Vote is striving to restore the democratic tradition (Follow My Vote, 2019a).

are evocative of many meanings directly linked to power relations surrounding technology and democracy. The uses of language here did not include conditional verb tenses: rather, it was stated, in the present tense, that democracy "can't function" as it currently is. This statement hints at the fact that it is technological ability and competence that allows for Follow My Vote to "striv(e) to restore the democratic tradition and that will find the solutions necessary for democracy to be "fixed." 
Thus, the sentence "Follow My Vote is striving to restore the democratic tradition" indicates, through a gerund implying continuity, that Follow My Vote is attempting this via their technology. This particular use of language may well imply a trend seen throughout this CDA, textually, discursively and societally: that technological ability gives developers agency to be able to perform this "striving to restore the democratic tradition" through their creative means and solutions. This conclusion ties up with the academic line of inquiry identified as technological determinism. Connotations of technology being able to solve a perceived democratic deficit demonstrate this. However, it is through a discursive analysis of the quote above that the implications of these start-ups' narratives for technological literacy can be perceived.

The discursive aspects of CDA raise many questions pertaining to intertextuality and audiences. The quote above suggests the Follow My Vote technology has the potential to "restore the democratic tradition." However, it also poses important concerns regarding the agency of others to contribute to the preservation of democracy. These queries are elicited because the agency of citizens with no technological skill or knowledge remained unaddressed and unaccounted for. There was a perceived scarcity of statements about the participation and contribution of citizens without technological skills, beyond actively voting for politicians and institutions within the boundaries set by these (as seen in my audience analysis in section "Who? Audiences and the Issue of Voice"). Follow My Vote assumed that democracy would be preserved if most or all citizens were voting, and thus assigned voters, who would employ the technology developed by the start-up, a passive role in shaping democracy's functional future. The text's connotations imply that voters with no technological skills or without institutional power are resigned to vote and nothing more. On the other hand, technologically skilled individuals, as well as the institutions they seek to collaborate with, can actively shape the governmental outcomes of society.

Among all the start-ups analyzed, Polys stood out as claiming to provide a platform where "no specific training or IT literacy is needed" and emphasizing that it "is a flexible application and can be easily customized for your particular needs" (Polys, $2019 b$, p. 3). They also emphasized the importance that complementary information and knowledge have in order to realize the promise of a more democratic society that technology can potentially bring about. By stating that "any attempts to improve the electoral system and democracy with the help of new technologies are meaningless without raising the level of voter awareness" (Polys, 2019a), Polys demonstrated a care and a need for additional qualities. Beyond individualism and beyond technological literacy it is the actual normative values that are important to maintain democracy. This demonstrates, on the part of Polys specifically, an acute emphasis on access to democracy in a way which, for them, is virtually made harder by bureaucracy and the impositions of an inefficient system. Regarding technology, Polys commented: "People make democracy-an online voting system is just an instrument for facilitating honest, transparent elections" (Polys, 2019a). Further and similar to this, Democracy Earth argued that "No technology will ever be able to satisfy democratic aspirations if it can only be understood by an elite" (Democracy Earth, 2019b, p. 8), and put Facebook and Google as examples of monopolistic technological companies that do not manage to ensure the rights to privacy and transparency of their user bases. Finally, Votem also emphasized the ease of the process: "With just a few taps, you can give voters a more powerful way to have their say from their mobile phone or secure web browser..." (Votem, 2019a).

As referenced above, it is interesting to note how these start-ups acknowledged the need for convenient, user-friendly technology for everyone in order to achieve democratic outcomes. However, most of the societal discourses leading to an improvement of democratic outcomes idealized technology and presented it as able to channel democracy in the right way, as aforementioned, in a highly technologically deterministic mode. They barely considered the fact that this technology might not initially be reachable by everyone. In fact, they disregarded discourses dealing with the digital divide (Warschauer, 2003) on the basis that most of the population is connected to the internet (International Telecommunications Union (ITU), 2018). As a result, BPE start-ups made little reference to promoting the skills that are necessary to participate in the creation of "solutions" to democracy through the use of their platforms. This is clearly a paradox in wide-reaching projects such as those I have analyzed.

\section{CONCLUSION}

In analyzing texts made available by BPE start-ups in their web pages, omissions related to widespread concerns regarding current implementations of BPE technologies stand out. These concerns have been recently summarized as follows:

(1) Blockchain technology does not solve the fundamental security problems suffered by all electronic voting systems. (...) (2) Electronic, online, and blockchain-based voting systems are more vulnerable to serious failures than available paper-ballotbased alternatives. (...) (3) Adding new technologies to systems may create new potential for attacks (Park et al., 2020, p. 19).

The above considerations led the authors to conclude that "blockchain-based voting methods fail to live up to their apparent promise" (Park et al., 2020, p. 19). Perhaps unsurprisingly for start-ups that wish to promote their products, these issues were not touched upon in their texts. This is especially poignant in the case of Voatz, perhaps the most secretive of the BPE start-ups analyzed (see above). An independent analysis of their BPE server carried out by Specter et al. (2020) through reverse engineering of their mobile app uncovered extreme security and privacy vulnerabilities that should preclude its use in electoral processes.

Likewise, allusions and mentions of community and empowering voters can be spotted sparingly, presenting ideas of 
radical change to existing power relations governing democracy that have made it fail. However, CDA findings overwhelmingly suggest that, rather than wishing to profoundly alter existing power relations to transform and revitalize democracy, BPE start-ups are ready to make little change beyond switching the ways in which citizens vote, essentially promoting the adoption of their technological solutions. Their understanding of democracy challenges existing definitions of the term. Those employed throughout this work emphasize a care for voters' rights, as well as a concern for upholding them after and beyond election (voting) time. For this to happen, a combination of the "power of the people," along with a legal enshrinement of individual rights, are necessary. This tension between communal, bottom-up power and institutional, reified power appears in academic research about democracy. Nevertheless, BPE start-ups do not address it and, instead, reduce the extent of democracy to its most procedural expression (voting) and address the blockchain's benefits to individual voters, foregoing any mention of the positives to life as a community within democracy. This raises some doubts as to what community and assembly in participation would look like (if at all) under BPE start-ups' ideal of democracy. Further to this, textual features show that BPE start-ups display a consideration for economics, with constant reference to their products' potential to increase incentive and efficiency. Altogether, they present an image whereby the economy and its individualistic concerns under capitalism take precedence over communitarian, emotional understandings of democratic association. Finally, the recurring idea that technology has a complete and utter capacity for transforming democracy for the better is found as a common trend throughout, and strongly echoes academic research trends on technological determinism in the 1990s. BPE start-ups' belief is so strong that it relegates any activities to promote democracy on the part of voters with no technological background to just voting. This seriously problematizes power relations, entrenched in prior positions and stagnant at a moment when world history and political history advance much faster than ever before (Virilio, 1986).

Overall, it can be concluded that BPE start-ups' conceptions of democracy from an individualized, atomized, economic perspective, solely enabled by technological operations are antidemocratic according to current definitions. They show a considerable lack of concern for the communal, emotional domain that has been crucial in present-day participative criticism of democracy seeking to reduce the democratic deficit (e.g., the Spanish Indignados movement; Errejón and Mouffe, 2016). In summary, while BPE platforms have a potential to solve problems related to the mechanics of voting, it is unlikely that, in their present design, they will contribute to revitalize democracy or advance democratizing aims.

These conclusions are relevant because the main frame employed by the selected BPE start-ups emphasizes a broad and normative message of democratic improvement through BPE technology, beyond the specific qualities of their product. The use of Fairclough's CDA allowed delimitation of the wide network of power relations involved in choosing certain framings of the products over others. The authority and expertise asserted by the texts describing technological products, such as those analyzed, creates a convoluted relationship between the creators of the technology, the targeted 'buyers' (e.g., Governments) and the ultimate "users" of the technology (citizens). My conclusions suggest that this relationship is one where the final users of the technology are referred to assiduously, and where the functionality of the technology in less technologically literate households is not even considered.

As a continuation of this research, it would be interesting to conduct a parallel CDA on governments' views and understanding of the use of new technologies, such as BPE, for the future of democratic systems. Setting up a thorough, attentive and informed dialog between both sides would make us gain a better appreciation of where views coming from technology and views coming from government overlap, and whether they are more mindful of other areas within the broad conception of democracy sustained here.

To conclude, this work opens up several avenues for future research, including those on public perceptions of politics on online platforms and their impact on participation and voting, online modes of civic engagement with partisan politics and their democratic outcomes, techno-politics and cyberactivism for a new democratic culture. It may also address and interrogate internet-mediated channels of communal participation in local and national politics and its consequences for current democracy, and might benefit from more overarching methodological understandings-grounded theory, mixed methods qualitative research, ethnographies, quantitative methods, ...-to achieve more concrete and sound conclusions within this field of research.

\section{DATA AVAILABILITY STATEMENT}

The original contributions presented in the study are included in the article/supplementary material, further inquiries can be directed to the corresponding author/s.

\section{AUTHOR CONTRIBUTIONS}

MI designed, carried out research, and wrote the manuscript.

\section{ACKNOWLEDGMENTS}

MI is the recipient of a "La Caixa" post-graduate fellowship. MI thanks Dr. Dylan Mulvin (LSE) for early advice and guidance, the participants in the "Crisis and Challenges of Democracy" workshop (CES, University of Coimbra, Portugal) for feedback on a preliminary version of this manuscript, and two knowledgeable reviewers for their critical insights into current limitations of BPE technologies regarding fundamental privacy, security and accountability rights. 


\section{REFERENCES}

Agora (2019a). Agora Web. Available online at: https://agora.vote (accessed July 1, 2019).

Agora (2019b). Agora Whitepaper. Available online at: https://www.agora.vote/s/ Agora_Whitepaper.pdf (accessed July 1, 2019).

Agre, P. (1994). Networking and Democracy. The Network Observer 1.4. Available online at: http://polaris.gseis.ucla.edu/pagre/tno/april-1994.html (accessed July 1, 2019).

Allen, D. W. E., Berg, C., and Lane, A. M. (2019). Cryptodemocracy: How Blockchain Can Radically Expand Democratic Choice. Lanham, MD: Lexington Books.

Altheide, D. L., and Schneider, C. J. (2013). Qualitative Media Analysis, 2nd Edn. London: SAGE.

American Council for Technology Industry Advisory Council (ACT-IAC) (2017). Blockchain Primer: Enabling Blockchain Innovation in the U.S. Federal Government, ACT-IAC Whitepaper. Available online at: https://www.actiac.org/ act-iac-white-paper-enabling-blockchain-innovation-us-federal-government (accessed July 1, 2019).

Ancelovici, M., Dufour, P., and Nez, H. (2016). Street Politics in the Age of Austerity: From the Indignados to Occupy. Amsterdam: Amsterdam University Press.

Arslanian, H., and Fischer, F. (2019). The Future of Finance: The Impact of FinTech, AI, and Crypto on Financial Services. Switzerland: Palgrave Macmillan.

Baym, N. K. (2015). Personal Connections in the Digital Age. 2nd ed. Cambridge, MA: Polity Press.

Beck, U. (1992). Risk Society: Towards a New Modernity. London: Sage.

Berryhill, J., Bourgery, T., and Hanson, A. (2018). Blockchains Unchained: Blockchain Technology and its Use in the Public Sector, OECD Working Papers on Public Governance, no. 28. Paris: OECD Publishing.

Bijker, W. E. (1995). Of Bicycles, Bakelites, and Bulbs: Toward A Theory of Sociotechnical Change. Cambridge, MA: MIT Press.

Bijker, W. E., Hughes, T. P., and Pinch, T. (1987). The Social Construction of Technological Systems: New Directions in the Sociology and History of Technology. Cambridge, MA: MIT Press.

Blessing, J., Gomez, J., Patiño, M., and Nguyen, T. (2020). Security Survey and Analysis of Vote-by-Mail Systems. arXiv [Preprint]. Available at: https://arxiv. org/pdf/2005.08427.pdf (accessed June 30, 2020).

Blommaert, J., and Bulcaen, C. (2000). Critical Discourse Analysis. Annu. Rev. Anthropol. 29, 447-466.

Brennan, G., and Buchanan, J. (1984). Voter Choice. Am. Behav. Sci. 2, 185-201.

Brennan, G., and Hamlin, A. (1998). Expressive voting and electoral equilibrium. Public Choice 95, 149-175.

Brennan, G., and Lomasky, L. (1993). Democracy and Decision: The Pure Theory of Electoral Preference. Cambridge, MA: Cambridge University Press.

Brennan, J. (2016). "The Ethics and Rationality of Voting," in The Stanford Encyclopedia of Philosophy, ed. E. N. Zalta.(Stanford, CA: Stanford University) doi: 10.4159/harvard.9780674497764.c8

Castells, M. (1998). The Information Age: Economy, Society and Culture. 3. Malden, MA: Blackwell Publishing.

Castells, M. (2012). Networks of Outrage and Hope: Social Movements in the Internet Age. London: Polity Press.

Corrado, A. (1996). "Elections in Cyberspace: Prospects and Problems," in Elections in Cyberspace: Toward A New Era in American Politics, eds A. Corrado and C. M. Firestone (Washington, DC: Aspen Institute).

Crick, B. (2002). Democracy. A Very Short Introduction. Oxford: Oxford University Press.

Curran, J. (2016). “The Internet of Dreams: Reinterpreting the Internet," in Misunderstanding the Internet, eds J. Curran, N. Fenton, and D. Freedman (London: Routledge), 1-47. doi: 10.4324/9781315695624-1

De Filippi, P., and Hassan, S. (2016). Blockchain Technology as a Regulatory Technology: From Code Is Law to Law Is Code. First Monday 21, 12. doi: 10.5210/fm.v21i12.7113

Democracy Earth (2019a). Democracy Earth Web. Available online at: https:// democracy.earth/ (accessed July 1, 2019).

Democracy Earth. (2019b). Democracy Earth Social Smart Contract Whitepaper. Available online at:https://github.com/DemocracyEarth/paper/blob/master/ The\%20Social\%20Smart\%20Contract.pdf (accessed July 1, 2019).

Deuze, M. (2007). Media Work. Cambridge, UK: Polity Press.
Diamond, L. (2010). Liberation Technology. J. Democracy 21, 61-83.

Downs, A. (1957). An Economic Theory of Democracy. New York, NY: Harper.

Ellul, J. (1964). The Technological Society. New York, NY: Vintage.

Errejón, I., and Mouffe, C. (2016). Podemos: In the Name of the People. London: Lawrence \& Wishart.

Fairclough, N. (1989). Language and Power. London: Longman.

Fairclough, N. (1992). Discourse and Social Change. Cambridge, UK: Polity Press.

Fairclough, N. (1995). Critical Discourse Analysis: The Critical Study of Language. London: Longman.

Fischer, C. S. (1992). America Calling: A Social History of the Telephone to 1940 Berkeley, CA: University of California Press.

Fitzi, G., Mackert, J., and Turner, B. S. (2018). Populism and the Crisis of Democracy. 3. London: Routledge.

Follow My Vote (2019a). Follow My Vote Web. Available online at: https:// followmyvote.com (accessed July 1, 2019).

Follow My Vote (2019b). Follow My Vote: The Future of Voting. Available online at: https://followmyvote.com/the-future-of-voting/ (accessed July 1, 2019).

Follow My Vote (2019c). Follow My Vote: Voting Systems Vulnerabilities. Available online at: https://followmyvote.com/voting-system-vulnerabilities/ (accessed July 1, 2019).

Foucault, M. (1968). Politics and the Study of Discourse. Ideol. Conscious. 3, 7-26.

Fuchs, C. (2011). Foundations of Critical Media and Information Studies. New York, NY: Routledge.

Fuchs, C. (2013). "Social Media and Capitalism," in Producing the Internet: Critical Perspective of Social Media, ed. T. Olsson (Gothenburg: Nordicom), 25-44.

Garnham, N. (1994). "Whatever Happened to the Information Society?" in Management of Information and Communication Technologies: Emerging Patterns of Control, ed. R. Mansell (London: ASLIB), 42-51.

Gibson, J. P., Krimmer, R., Teague, V., and Pomares, J. (2016). A Review of E-voting: The Past, Present and Future. Ann. Telecommun. 71, 279-286. doi: 10.1007/s12243-016-0525-8

Gill, R. (1996). "Discourse Analysis: Practical Implementation," in Handbook of Qualitative Research Methods for Psychology and the Social Sciences, ed. J. T. E. Richardson (London: BPS-Blackwell), 141-156.

Gill, R. (2000). "Discourse Analysis," in Qualitative Researching with Text, Image and Sound: A Prectical Handbook, eds M. W. Bauer and G. Gaskell (London SAGE), 172-190.

Goodman, R., and Halderman, J. A. (2020). Internet Voting is Happening Now. Slate 15:2020.

Gronke, P., Galanes-Rosenbaum, E., Miller, P. A., and Toffey, D. (2008) Convenience Voting. Annu. Rev. Pol. Sci. 11, 437-455.

Grossback, L. J., Peterson, D. A. M., and Stimson, J. A. (2007). Mandate Politics. Cambridge, UK: Cambridge University Press.

Grossman, L. K. (1996). The Electronic Republic: Reshaping American Democracy for the Information Age. New York, NY: Viking.

Hegel, G. W. F. (1991). Elements of the Philosophy of Right. Cambridge, UK: Cambridge University Press.

Hillman, A. L. (2010). Expressive Behavior in Economics and Politics. Eur. J. Pol. Econ. 26, 403-418. doi: 10.1016/j.ejpoleco.2010.06.004

International IDEA (2019). The Global State of Democracy 2019: Addressing the Ills, Reviving the Promise. Stockholm: International IDEA, doi: 10.31752/idea.2019. 31

International Telecommunications Union (ITU) (2018). Measuring the Information Society Report 2018, Executive Summary.Available online at: https://www.itu.int/en/ITU-D/Statistics/Documents/publications/misr2018/ MISR2018-ES-PDF-E.pdf (accessed August 1, 2019).

Jenkins, H. (2008). Convergence Culture: Where Old and New Media Collide. New York, NY: New York University Press.

Juels, A., Eyal, I., and Naor, O. (2018). Blockchains won't fix internet voting security- and could make it worse. Conversation 18:2018.

Kapilkov, M. (2020). Russia Pilots Federal Voting on Waves Blockchain. Cointelegraph 19:2020.

Krimmer, R. (2012). The Evolution of E-voting: Why Voting Technology Is Used and How It Affects Democracy. Ph.D. Thesis Tallinn: Tallinn University of Technology.

Kuenzi, R. (2019). These Are the Arguments That Sank E-voting in Switzerland. Swissinfo 2:2019. 
Lessig, L. (2006). Code: And Other Laws of Cyberspace. Version 2.0. New York, NY: Basic Books.

Levin, Y. (2002). Politics After the Internet. Public Interest 149, 80-94.

List, C. (2013). "“Social Choice Theory,", in The Stanford Encyclopedia of Philosophy, ed. E. N. Zalta.(Stanford, CA: Stanford University).

MacKenzie, D., and Wajcman, J. (eds) (1989). The Social Shaping of Technology, 2nd Edn. Buckingham, UK: Open University.

Mackie, G. (2015). "Why It's Rational to Vote," in Rationality, Democracy, and Justice: The Legacy of Jon Elster, eds C. López-Guerra and J. Maskivker (Cambridge, UK: Cambridge University Press), 21-49. doi: 10.1017/ cbo9781107588165.005

Mansbridge, J. J. (ed.) (1990). Beyond Self-Interest. Chicago, IL: University of Chicago Press.

Markus, M. L. (1994). Finding the Happy Medium: Explaining the Negative Effects of Electronic Communication on Social Life at Work. ACM T. Inform. Syst. 12, 119-149. doi: 10.1145/196734.196738

McAllister, I. (2016). Internet Use, Political Knowledge and Youth Electoral Participation in Australia. J. Youth Stud. 19, 1220-1236. doi: 10.1080/13676261. 2016.1154936

McLean, I., and Hewitt, F. (1994). Condorcet: Foundations of Social Choice and Political Theory. Cheltenham, UK: Edward Elgar.

McLuhan, M. (1964). Understanding Media: The Extensions of Man. New York, NY: McGraw-Hill.

National Academies of Sciences, Engineering, and Medicine (2018). Securing the Vote: Protecting American Democracy. Washington, DC: The National Academies Press, doi: 10.17226/25120

Noel, H. (2010). Ten Things Political Scientists Know that You Don't. The Forum 8:12. doi: $10.2202 / 1540-8884.1393$

Nye, D. E. (1997). Narratives and Spaces: Technology and the Construction of American Culture. New York, NY: Columbia University Press.

Papacharissi, Z. (2014). Affective Publics: Sentiment, Technology, and Politics. New York. Oxford: Oxford University Press.

Park, S., Specter, M., Narula, N., and Rivest, R. L. (2020). Going from Bad to Worse: From Internet Voting to Blockchain Voting. Semantic Scholar [Preprint]. Available online at: https://www.semanticscholar.org/paper/ Going-from-Bad-to-Worse\%3A-From-Internet-Voting-to-Park-Narula/ d60e045731228b1118918cbd8cc41f2e19ac143f (accessed June 30, 2020).

Poblet, M., Casanovas, P., and Rodríguez-Doncel, V. (2019). Linked Democracy: Foundations, Tools, and Applications. Switzerland: Springer Open.

Polys. (2019a). Polys Web. Available online at: https://polys.me (accessed July 1, 2019).

Polys. (2019b). Polys Whitepaper. Available online at: https://polys.blob.core. windows.net/site/Polys_whitepaper.pdf (accessed July 1, 2019).

Poster, M. (2001). What's the Matter with the Internet. Minneapolis, MN: University of Minnesota Press.

Rash, W. Jr. (1997). Politics on the Nets: Wiring the Political Process. San Francisco, CA: W.H. Freeman.

Richey, S., and Zhu, J. (2015). Internet Access Does Not Improve Political Interest, Efficacy, and Knowledge for Late Adopters. Pol. Commun. 32, 396-413. doi: 10.1080/10584609.2014.944324

Robins, K., and Webster, F. (1988). "Cybernetic Capitalism: Information, Technology, Everyday Life," in The Political Economy of Information, eds V. Mosko and J. Wasko (Madison, WI: University of Wisconsin press), 45-75.

Schroeder, R. (2007). Rethinking Science, Technology, and Social Change. Palo Alto, CA: Stanford University Press.
Shirky, C. (2009). Here Comes Everybody: The Power of Organizing Without Organizations. London: Penguin.

Specter, M., Koppel, J., and Weitzner, D. (2020). The Ballot is Busted Before the Blockchain: A Security Analysis of Voatz, the First Internet Voting Application Used in U.S.Federal Elections. Available online at: https://internetpolicy.mit. edu/securityanalysisofvoatz_public/ (accessed November 27, 2020).

Taylor, S. (2013). What Is Discourse Analysis?. London: Bloomsbury.

Thomason, J., Bernhardt, S., Kansara, T., and Cooper, N. (2019). Blockchain Technology for Global Social Change. Hershey, PA: IGI Global.

Toffler, A. (1980). The Third Wave. New York, NY: Bantam.

Toffler, A., and Toffler, H. (1995). Creating A New Civilization: The Politics of The Third Wave. Atlanta, GA: Turner.

Van Dijck, J., and Nieborg, D. (2009). Wikinomics and its Discontents: A Critical Analysis of Web 2.0 Business Manifestos. New Media Soc. 5, 855-874. doi: $10.1177 / 1461444809105356$

Van Niekerk, M. (2019). How Blockchain Strengthened Indonesian Democracy (And Could Do The Same Elsewhere). Forbes, May 23, 2019. Available online at: https://www.forbes.com/sites/worldeconomicforum/2019/05/23/ how-blockchain-strengthened-indonesian-democracy-and-could-the-sameelsewhere/\#6d32cf252c3a (accessed November 28, 2020).

Virilio, P. (1986). Speed and Politics: An Essay on Dromology. New York, NY: Columbia University

Voatz (2019). Voatz Web. Available online at: https://voatz.com (accessed July 1, 2019).

Votem (2019a). Votem Web. Available online at: https://votem.com (accessed July $1,2019)$.

Votem (2019b). Votem Proof of Vote Whitepaper. Available online at: https: //github.com/votem/proof-of-vote/blob/master/proof-of-vote-whitepaper.pdf (accessed July 1, 2019).

VoteWatcher (2019). VoteWatcher Web. Available online at: https://votewatcher. com (accessed July 1, 2019).

Warschauer, M. (2003). Technology and Social Inclusion: Rethinking the Digital Divide. Cambridge, MA: MIT Press.

Winner, L. (1977). Autonomous Technology: Technics-out-of-Control as a Theme in Political Thought. Cambridge, MA: MIT Press.

Winner, L. (1989). "Do Artifacts Have Politics?" in The Social Shaping of Technology, eds D. MacKenzie and J. Wajcman (Buckingham, UK: Open University), 28-40.

Wodak, R. (2014). "Critical Discourse Analysis," in The Routledge Companion to English Studies, eds C. Leung and B. V. Street (London: Routledge), 302-317.

Wodak, R., and Meyer, M. (2009). "Critical Discourse Analysis: History, Agenda, Theory, and Methodology," in Methods for Critical Discourse Analysis, eds R. Wodak and M. Meyer (London: SAGE), 1-33.

Conflict of Interest: The author declares that the research was conducted in the absence of any commercial or financial relationships that could be construed as a potential conflict of interest.

Copyright (c) 2021 Imperial. This is an open-access article distributed under the terms of the Creative Commons Attribution License (CC BY). The use, distribution or reproduction in other forums is permitted, provided the original author $(s)$ and the copyright owner(s) are credited and that the original publication in this journal is cited, in accordance with accepted academic practice. No use, distribution or reproduction is permitted which does not comply with these terms. 